\title{
LUT
}

University

\section{Personal resources and knowledge workers' job engagement}

\author{
Toth Ilona, Heinänen Sanna, Nisula Anna-Maija
}

This is a Author's accepted manuscript (AAM) version of a publication

published by Emerald Publishing

in International Journal of Organizational Analysis

DOI: $10.1108 /$ IJOA-07-2019-1830

Copyright of the original publication: (C) 2019, Emerald Publishing

Please cite the publication as follows:

Toth, I., Heinänen, S., Nisula, A.-M. (2020). Personal resources and knowledge workers' job engagement. International Journal of Organizational Analysis. DOI: 10.1108/IJOA-07-2019-1830

This is a parallel published version of an original publication.

This version can differ from the original published article. 


\section{Personal resources and knowledge workers' job engagement}

\begin{tabular}{|r|l|}
\hline Journal: & International Journal of Organizational Analysis \\
\hline Manuscript ID & IJOA-07-2019-1830.R1 \\
\hline Manuscript Type: & Original Article \\
\hline Keywords: & Knowledge workers, Personal resources, Job engagement \\
\hline \multicolumn{2}{l}{} \\
\end{tabular}

SCHOLARONE $^{\text {MT }}$

Manuscripts 


\section{Personal resources and knowledge workers' job engagement}

Purpose: The purpose of this paper is to investigate the impact of personal resources on knowledge workers' job engagement in the contemporary economy. Work itself and work environments are currently undergoing fundamental changes. As such, the focus of engagement research is shifting to an interest in personal resources and the psychological capital of knowledge workers.

Design/methodology/approach: This paper proposes a theoretical model based on a modern interpretation of the Conservation of Resources Theory concerning the relationship between personal resources (self-efficacy, organization-based self-esteem, and satisfaction with life) in relation to the three dimensions of job engagement (physical, emotional, and cognitive). The proposed model is tested with structural equation modelling (LISREL).

Findings: Results from the analysis of data collected from Finnish university graduates $(\mathrm{N}=$ 103) show that the three dimensions of job engagement are strongly influenced by organizationbased self-esteem and satisfaction with life but, surprisingly, not by self-efficacy.

Practical implications: Through understanding the impact of personal resources on knowledge workers' job engagement, organizations can enhance their human relations management practices and develop better support mechanisms for their knowledge workers.

Originality/value: This paper provides empirical evidence for the influence of personal resources on knowledge workers' job engagement. There is a lack of empirical studies on knowledge workers' job engagement in the contemporary economy. The changing nature of the 
way work is being carried out in the contemporary economy raises the importance of personal resources as a key resource for knowledge workers' job engagement.

Keywords: Knowledge worker, personal resources, job engagement.

Paper type: Research paper. 


\section{Introduction}

Currently, work and work environments are undergoing fundamental changes. This has led to an increasing number of employees who are categorized as knowledge workers; that is, employees who continuously orchestrate and generate knowledge (Davenport et al., 2002) in their day-today work for better production and performance (Dul et al., 2011). Atkins (1999) and Rüdiger and McVerry (2007) suggest that university graduates in the 21 st century can be classified as knowledge workers, possessing "a combination of subject-specific skills and knowledge, generic intellectual skills, generic process skills, competencies and personal attributes” (Atkins, 2009, p. 277). The key characteristics of modern knowledge work - growth of autonomy and demand for flexibility in work arrangements as a consequence of digitalization, a growing need for an entrepreneurial attitude regarding expert knowledge tasks, and a desire for work challenges (e.g., Scarbrough, 1999; Kelloway and Barling, 2000) — differentiate knowledge work from conventional organizational employee work. Given the diversity and heterogeneity of knowledge workers, individual aspects are emphasized in explaining knowledge work.

Knowledge-intensive work is based on low capital intensity and a highly professionalized workforce (Von Nordenflycht, 2010). Both of these matters are of particular importance for the creation of sustainable competitive advantage. The competitive advantage of engaged employees is based on their ability to be innovative and to take the initiative in restructuring their job resources in conformity with organizational goals (Turner and Pennington, 2015). This poses a challenge to management (Burke and $\mathrm{Ng}, 2006$ ), as they must figure out how to keep individuals productive and engaged in what they are doing. Contemporary work life provides unprecedented opportunities for knowledge workers; however, it also requires that these knowledge workers have sufficient personal resources to cope with and master their freedom in a working life of constant change and uncertainty (Grawitch et al., 2010; Imperatori, 2017). 
In such a challenging work life, job engagement is critical for knowledge workers (Sullivan et al., 2007). Personal work-related engagement is a result of motivation, especially intrinsic motivation (Schaufeli, 2013; Hallberg and Schaufeli, 2006). This has been conceptualized as the investment of an individual's complete self into a work role (Rich et al., 2010). As such, job engagement is one of the key drivers of successful work performance (Rich et al., 2010), as it has both individual and organizational consequences. Even though the importance of job engagement for productive work (Luthans and Youssef, 2004; Bakker and Demerouti, 2008) and employee well-being (Hakanen et al., 2012; Schaufeli et al., 2008) has been widely recognized, surprisingly few studies have acknowledged — particularly in the context of knowledge workthat personal resources could act as important antecedents of job engagement. Indeed, several scholars have recognized the lack of empirical research on job engagement in the knowledge work context (Gilson et al., 2015; Hakanen, 2009; O’Neill et al., 2014).

In earlier studies, the role of individuals' personal resources as a predictor of desirable workrelated outcomes and their role as an important factor as antecedents to engagement in conventional organizational settings has been acknowledged by several researchers (Bakker et al., 2011; Rich et al., 2010; Saks and Gruman, 2014; Schaufeli and Bakker, 2010; Schaufeli and Salanova, 2007; Sweetman and Luthans, 2010; Van Wingerden et al., 2015; Xanthopoulou et al., 2009). However, few studies have addressed personal resources in the context of knowledge work, even though personal resources are critical to success in changing work conditions. For example, O’Neill et al. (2014) argued that an individual's personality plays an important role in that individual's assessment of their self-management skills and capabilities for distributed work.

To address the identified research gap, the current study investigates the impact of personal resources of self-efficacy, organization-based self-esteem, and satisfaction with life on job engagement among knowledge workers. This research paper asks the following question: Which 
personal resources influence knowledge workers' job engagement? After conducting a literature review, a theoretical model is proposed based on a modern interpretation of the Conservation of Resources Theory (Schaufeli and Salanova, 2007) and on the experience of work engagement and its antecedents and outcomes (Schaufeli, 2013). This model is used to investigate the relationship between job engagement and personal resources.

The theoretical approach is discussed in the following section. After hypothesis formation, measurement of latent concepts and data collection issues are introduced. In the empirical part of the study, structural equation modelling is used for testing the proposed hypotheses using a dataset $(\mathrm{N}=103)$ collected from graduates of a Finnish university. The final chapter of the paper discusses the findings and their implications for contemporary knowledge workers.

\section{Theoretical background and hypotheses}

The notion of job (or work) engagement ${ }^{1}$ originates from Kahn's (1990) discussion of personal work-related engagement. For Kahn (1990), work-related engagement consists of three equally important psychological states: meaningfulness, safety, and availability. Personal engagement is defined as “the simultaneous employment and expression of a person's 'preferred self' in task behaviors that promote connections to work and to others, personal presence (physical, cognitive, and emotional), and active, full role performances" (Kahn, 1990, p. 700). The

\footnotetext{
${ }^{1}$ In this paper the concepts of job engagement and work engagement are used interchangeably according to the preference of the reference cited, as no scientifically established distinction between the two concepts exists.
} 
employment and expression of a "preferred self" can lead to both engagement and disengagement at work. The latter has been found to be costly to businesses worldwide (Saks and Gruman, 2014).

Interest in work-related engagement has coincided with a rising interest in the positive psychology movement, which was founded by Seligman and Csikszentmihalyi (2000) in the early 21 st century. Most scholars define work-related engagement as a three-dimensional construct, though there is also evidence for the unidimensionality of the construct (e.g., Sonnentag, 2003).

One of the most commonly cited definitions of work engagement comes from Schaufeli et al. (2002, p. 74), who define it "as a positive, fulfilling work-related state of mind that is characterized by vigor, dedication, and absorption." "Vigor" refers to high levels of energy and resilience, "dedication" refers to strong involvement in work, and "absorption" refers to a pleasant state of work immersion (Yalabik et al., 2015). Schaufeli et al. (2002) constructed their framework for engagement out of different theoretical models (Table 1). Following the work of Kahn (1990), Schaufeli et al. (2002) highlighted the positive psychological and attitudinal aspects of work.

$<<<$ Please insert Table 1 about here $>>>$

Personal resources describe an individual's belief that they can influence their environment successfully. In the research literature, the terms "personal resources" (Luthans et al., 2007; Van 
Wingerden et al., 2015; Xanthopoulou et al., 2009) and "positive psychological capital" (Luthans et al., 2010) both refer to these malleable personal attributes. An individual with sufficient personal resources is likely to master the balance between situational and personal resource management (Wingerden et al., 2015) and to perform successfully in a variety of circumstances (Bakker et al., 2012b). While mastering the balance between personal resources and work demands, individuals simultaneously maintain and develop new resources. This refers to the modern interpretation of the Conservation of Resources Theory (Hobfoll, 1989), according to which individuals in challenging work circumstances — such as in knowledge work-continuously develop their personal resources (Hobfoll, 2011) in relation to work demands.

Personal resources can predict desirable work-related outcomes. They can also function as important predictors of work engagement because the more significant these personal resources are, the more such individuals in possession of them are intrinsically motivated to pursue their goals, which results in higher performance (Bakker et al., 2011; Bakker et al., 2008). In the research literature, an individual's personal resources are understood to be composed of different elements. The most commonly used personal work-related resource theory is that of Luthans and Youssef (2004), which involves four concepts or dimensions: self-efficacy, hope, optimism, and resilience. In addition to these four most commonly mentioned attributes, happiness, compassion, and emotional intelligence (Luthans and Youssef, 2004), as well as self-esteem (Airila et al., 2014; Bakker and Demerouti, 2008), have also been listed among work-related personal resources. The concept of life satisfaction involves hope and optimism (Bailey et al., 2007); as such, these qualities are included in most descriptions of personal resources.

The present study investigates the personal resources of general self-efficacy, organization-based self-esteem, and satisfaction with life in relation to a heterogeneous group of knowledge workers' job engagements. These personal resources have all shown a positive relationship with 
job engagement in previous studies (Hakanen et al., 2012). However, their influence as antecedents to job engagement among knowledge workers has not previously been studied, even though these attributes appear to be vital for knowledge workers.

The present study approaches job engagement through Rich et al.'s (2010) three-dimensional concept consisting of physical, emotional, and cognitive engagement. The attributes included in Rich et al.'s (2010) measure bear important similarities to Kahn's (1992) definition of personal engagement at work, which also includes physical, emotional, and cognitive behavior.

\section{Self-efficacy and knowledge workers' job engagement}

As a concept, self-efficacy originates from Bandura's (1977) Social Cognitive Theory (SCT), which argues that individuals are able to master their goals and performance through selfefficacy beliefs. As such, individuals with high confidence believe in their own capabilities to conduct a required task. Luthans and Youssef (2004) define self-efficacy as “one's confidence in his or her ability to mobilize the motivation, cognitive resources, and courses of action necessary to execute a specific course of action within a given context” (p. 153). Self-efficacy is strongly related to an individual's own skills, knowledge, and competencies; it can be task- or domainspecific or belong to a wider concept known as general self-efficacy (Scholz et al., 2002; Sherer et al., 1982). While domain-specific self-efficacy (e.g., creative self-efficacy) refers to one specific domain, general self-efficacy (Chen et al., 2001) refers to one's confidence in dealing with demands across a wide variety of situations (Bandura, 1993; Bandura, 1997; Chen et al., 2001). By nature, self-efficacious people look for challenging tasks and are highly motivated to accomplish their goals successfully (Luthans and Youssef, 2004). 
Previous studies of work-related engagement in organizational settings have shown that general self-efficacy contributes to employee engagement (Consiglio et al., 2016; Salanova et al., 2002; van Wingerden et al., 2015). On the basis of the above, it is expected that general self-efficacy is especially important for job engagement, particularly in knowledge-intensive work where individuals autonomously set and work toward their own goals. Therefore, it is hypothesized that:

H1a: General self-efficacy is positively related to knowledge workers' physical job engagement. $H 1 b$ : General self-efficacy is positively related to knowledge workers' emotional job engagement.

H1c: General self-efficacy is positively related to knowledge workers' cognitive job engagement.

\section{Organization-based self-esteem and knowledge workers' job engagement}

Pierce et al. (1989) introduced the concept of organization-based self-esteem on the grounds that people with high levels of self-esteem would develop and maintain favorable work attitudes (e.g., work satisfaction) but saw that the global level of self-esteem was not sufficient for organizational research. Individuals maintain self-esteem by having faith in a culturally derived conception of reality (the cultural worldview) and by living up to the values prescribed by their worldview (Greenberg et al., 1992). The members of an organization can be seen as individuals satisfying needs. On this basis, organization-based self-esteem is defined by Pierce et al. (1989) as "the degree to which organizational members believe that they can satisfy their needs by 
participating in roles within the context of an organization" (p. 625). People who experience high levels of organization-based self-esteem have a sense of personal adequacy as organizational members; they perceive themselves as important, meaningful, and worthwhile members in their respective organizations. In a wide-ranging review, Pierce and Gardner (2004) found that organization-based self-esteem was related to job satisfaction, organizational commitment, motivation, citizenship behavior, in-role performance, and turnover intentions, as well as other important organization-related attitudes and behaviors.

In the knowledge worker context, organization-based self-esteem means that employees have a positive view of their worth and value as members of their organization (Mauno et al., 2007). Forret and Dougherty (2001) and Thompson (2005) found that individuals with high self-esteem were more likely to engage in networking behaviors. In their two-year follow-up study, Xanthopoulou et al. (2009) found that organization-based self-esteem had a reciprocal relationship with work engagement, and Hakanen et al. (2012) also established a connection between positive self-evaluation (i.e., self-esteem) and engagement. As such, the following hypotheses are posited:

H2a: Organization-based self-esteem is positively related to knowledge workers' physical job engagement.

$H 2 b$ : Organization-based self-esteem is positively related to knowledge workers' emotional job engagement.

$H 2 c$ : Organization-based self-esteem is positively related to knowledge workers' cognitive job engagement. 
Satisfaction with life and knowledge workers' job engagement

Erdogan et al. (2012) acknowledge that the management research field does not have an unambiguous answer to the question of what contribution the work domain makes to life satisfaction. Though much research has been conducted on job satisfaction, the influence of life satisfaction on work has not been thoroughly discussed. Life satisfaction is defined as "a global assessment of a person's quality of life according to his chosen criteria" (Shin and Johnson, 1978, p. 478) and is seen as consisting in hope and optimism (Bailey et al., 2007) —both of which are commonly considered as personal resources. The Satisfaction with Life Scale (SWLS) has been widely used around the world for measuring well-being and overall happiness in life (Diener et al., 1999). According to Barrick et al. (2013), there is evidence from several empirical studies showing that individual differences in personal resources and psychological capital play a significant role in explaining employee motivation and behavior. Higher life satisfaction facilitates positive work-related outcomes, such as job performance and commitment (Erdogan et $a l ., 2012)$. On the basis of all this, the following hypotheses concerning an individual's general life satisfaction are posited:

$H 3 a$ : Satisfaction with life is positively related to knowledge workers' physical job engagement.

$H 3 b$ : Satisfaction with life is positively related to knowledge workers' emotional job engagement.

$H 3 c$ : Satisfaction with life is positively related to knowledge workers' cognitive job engagement. 


\section{Research model}

While previous studies have based their research models on the idea that work engagement is the opposite of burnout (Maslach et al., 2001), the research model in this study is built on a modern interpretation of the Conservation of Resources Theory (Hobfoll, 1989), which argues that people strive to obtain, retain, and protect their personal resources (Schaufeli and Salanova, 2007). Abubakar et al. (2019) have recently also used the Conservation of Resources Theory in explaining the influence of certain human resource practices on the fostering of employees' psychological capital.

Schaufeli (2013) also demonstrates the role of personal resources in the development of work engagement. Xanthopoulou et al.'s (2009) findings support the assumption that various types of job resources and personal well-being evolve into a gain cycle determining an employee's adaptation to their work environment. Seen together, these results confirm that "engaged employees are characterized by high levels of personal resources (and particularly self-efficacy) that broaden their autonomy to change tasks or relational boundaries" (Bakker et al., 2012a, p. 19), which is crucial for knowledge workers.

The research model in Figure 1 summarizes the hypotheses to be tested in order to capture the interrelationships between job engagement and the following attributes: general self-efficacy, organization-based self-esteem, and satisfaction with life.

$<<<$ Please insert Figure 1 about here $>>>$ 


\section{Methodology}

\section{Data collection}

Data collection was targeted to university graduates as they represent a heterogeneous group of knowledge workers. The data was collected with a questionnaire sent to graduates of a university in Southern Finland via a web link in an electronic newsletter. The survey was open for one month. During that time, 172 respondents answered the questionnaire. Due to missing values in responses, the effective sample size was 103 responses. Of the respondents, $58.7 \%$ were male, $39.0 \%$ were female, and $2.3 \%$ did not state their gender. Most of the respondents $(65.7 \%)$ were 25-44 years of age. A clear majority of the responders held a bachelor's or a master's degree in science $(65.7 \%)$ as their most recently obtained academic degree.

$59.9 \%$ of the respondents had graduated from university within six years. $83.7 \%$ of respondents were working as employees in organizations, which included professional services $(12.2 \%)$, education $(8.7 \%)$, information technology $(18.6 \%)$, manufacturing $(19.8 \%)$, financial services (6.4\%), healthcare services $(1.7 \%)$, telecommunications $(5.8 \%)$, consumer goods $(2.9 \%)$, the energy sector (7.6\%), media and publishing (1.2\%), the public sector $(9.9 \%)$, and retail $(1.7 \%)$. $3.5 \%$ of the respondents did not define the primary industry they were working in.

\section{Measurement}

The concepts included in the research model were treated as latent constructs and measured with multiple items. The items were statements, and the respondents were asked to register their 
agreement or disagreement with each statement on a seven-point Likert scale varying from $1=$ completely disagree to $7=$ completely agree.

Job engagement as the dependent concept was measured with 13 items from Rich et al.'s (2010) Job Engagement Scale. The scale has three dimensions for engagement: (1) emotional engagement is measured with six items, (2) physical engagement is measured with four items, and (3) cognitive engagement is measured with four items. Examples of measurement items are "I work with intensity on my job" for physical engagement, "I am proud of my job" for emotional engagement, and "At work, I concentrate on my job" for cognitive engagement. Some of the original items were rephrased where it was deemed necessary to do so.

The independent concepts were all measured with multiple item scales obtained from previous research. General self-efficacy was measured with four items from Chen et al.'s (2001) SelfEfficacy Scale. Organization-based self-esteem was measured with five items from Pierce et al.'s (1989) Organization-based Self-esteem (OBSE) scale. Finally, satisfaction with life was measured with three items from Diener et al.'s (1985) SWLS. Examples of measurement items are "I will be able to successfully overcome many challenges" for general self-efficacy, "I count around here" for OBSE, and "I am satisfied with my life" for SWLS.

Measurement validation was conducted with confirmatory factor analysis using maximum likelihood estimation with LISREL. Due to the sample size and the complexity of the measurement model, the independent variables and the measurement of engagement were analyzed separately. Table 2 includes the results of the measurement model related to the explanatory variables: namely, self-efficacy, organization-based self-esteem, and satisfaction with life. The model fit was relatively good. The item loadings were all higher than .700 and statistically significant. Based on loadings and error variance, the measurement reliability was 
assessed with composite reliability (CR) and level of average variance extracted (AVE). The general acceptance levels are .700 for CR and .500 for AVE (see, e.g., Diamantopoulos and Siguaw, 2000; Fornell and Larcker, 1981). Therefore, it can be concluded that the measurement of the independent constructs meets the established criteria for reliable measurement.

$<<<$ Please insert Table 2 about here $>>>$

The dimensions of job engagement were also analyzed with confirmatory factor analysis. The measurement model for job engagement is presented in Table 3. The model produced good fit statistics and the reliabilities were at excellent levels.

$<<<$ Please insert Table 3 here $>>>$

\section{Results}

Structural equation modelling with maximum likelihood estimation was applied for the testing of the hypotheses using LISREL. Due to the small sample size and the rather complex measurement model, summated scales were partly used instead of the full measurement model. Summated scales for each independent latent construct were computed based on the results of confirmatory factor analysis and then the indicator error variance was computed for the structural model based 
on summated scale variances and the composite reliability of latent constructs (see, e.g., Childers et al., 2001; Fisher and Price, 1992). Three models were analyzed, one for each dimension of job engagement.

The results of the modelling are presented in Table 4, which outlines the standardized path coefficients and their significance levels as well as the fit statistics of the models. Considering the overall model fit, the results suggest quite good fits to the data in all three individual models.

The first model concerned personal resources and physical engagement. These results indicated that organization-based self-esteem is significantly related to physical engagement; that is, the higher the organization-based self-esteem, the higher the level of physical engagement. In addition, satisfaction with life positively influenced physical engagement, though the level of significance was quite low.

In the second model, emotional engagement was explained with personal resources. In this case, the results were similar to the first model. However, the influence of life satisfaction was stronger, though not as strong as the effect of organization-based self-esteem.

The third model focused on the cognitive dimension of engagement, and the results were almost equal to those of physical engagement. The highest and most significant coefficients were found between organization-based self-esteem and cognitive engagement. Satisfaction with life also had a positive relationship with cognitive engagement but with low statistical significance.

$<<<$ Please insert Table 4 about here $>>>$ 
It seems that the explanatory power of personal resources was most prominent in the emotional dimensions of job engagement $\left(\mathrm{R}^{2}=0.45\right)$. As such, the proposed hypotheses were only partly supported. The first set of hypotheses (H1a, H1b, and H1c) predicted a positive relationship between general self-efficacy and job engagement. However, based on all three models, the analysis of structural paths did not support this set of hypotheses. The estimated path coefficients were negative, though insignificant in the models of physical and emotional engagement. The standardized coefficient for cognitive engagement was positive, as predicted in the hypotheses, though it was also insignificant.

The next set of hypotheses $(\mathrm{H} 2 \mathrm{a}, \mathrm{H} 2 \mathrm{~b}$, and $\mathrm{H} 2 \mathrm{c})$ predicted that organization-based self-esteem has a positive relationship with job engagement. The results supported this prediction. Organization-based self-esteem had a strong and positive influence on engagement in all its dimensions. The influence of organization-based self-esteem was especially high on emotional and physical engagement, although the overall share of variance explained in physical engagement was smallest.

Finally, the third set of hypotheses (H3a, H3b, and H3c) addressed the influence of life satisfaction on job engagement. The results suggested that the relationship between these two constructs was, as predicted, positive and significant. The hypotheses were, therefore, supported. However, the standardized path coefficients were much smaller compared to the paths from organization-based self-esteem to engagement dimensions. 


\section{Discussion and conclusions}

The present study has addressed an important research gap in knowledge workers' job engagement in contemporary work life by investigating the impact of personal resources on the job engagement of a heterogeneous group of knowledge workers. More specifically, this study investigated the relation of three personal resources — general self-efficacy, organization-based self-esteem, and satisfaction with life — to knowledge workers' job engagement. The results show that both organization-based self-esteem and satisfaction in life are important and contribute to knowledge workers' job engagement.

\section{Theoretical implications}

Theoretically, the present study contributes to the literature on work-related engagement (Saks, 2006; Saks and Gruman, 2014; Schaufeli, 2013; Shuck, 2011) by providing empirical evidence of the impact of personal resources on knowledge workers' job engagement. In particular, the study shows that knowledge workers who experience high levels of organization-based selfesteem are highly engaged to perform their work tasks. This finding is consistent with past studies, which have found a relationship between organization-based self-esteem and employee engagement (Hakanen et al., 2012; Xanthopoulou et al., 2009). As such, this finding expands on earlier research by showing that the relationship is also positive and strong in a heterogeneous knowledge worker context. The study results also show that satisfaction with life positively contributes to knowledge workers' job engagement. This finding aligns with, and adds to, previous studies (Forret and Dougherty, 2001; Thompson, 2005) by showing that satisfaction with life has an impact on knowledge workers' job engagement. 
Contrary to expectations, general self-efficacy was shown not to be related to knowledge workers' job engagement. This is in contrast to the earlier findings of Salanova et al. (2002) and Salanova et al. (2003), who found a positive connection between general self-efficacy and work engagement in the contexts of information technology workers and university psychology students. However, the study of Salanova et al. (2006) showed that general self-efficacy mediates the relationship between a positive outlook on life and work engagement. This finding may also explain the results in this study, as only the direct impact of general self-efficacy on job engagement was examined. As such, this study did not account for the possible presence-as found in previous studies _ of mediating or moderating causes acting between the two variables.

Furthermore, our findings contribute to the research on employee personal resources (Luthans et al., 2007; Van Wingerden et al., 2015; Xanthopoulou et al., 2009) by investigating personal resources among knowledge workers and showing that, indeed, personal resources of organization-based self-esteem and satisfaction with life are important for knowledge workers' job engagement. Hence, our findings expand our understanding of the positive role of personal resources (e.g., O’Neill et al., 2014) by confirming that personal resources are important for knowledge workers' job engagement.

Boundaryless careers, together with demands for flexibility, are becoming the new norm in many occupations, particularly with knowledge workers (Hakanen et al., 2012). The present study contributes to the growing body of research on knowledge work and the variety of forms it takes in contemporary work life by showing that personal resources are important, influencing physical, emotional, and cognitive job engagement among an occupationally heterogeneous group of knowledge workers. As such, this study makes an important contribution to the understanding of the role of knowledge workers' personal resources in contemporary work life. 


\section{Practical implications}

For knowledge workers in boundaryless careers - that is, independent knowledge workers who are responsible for the development and maintenance of their personal resources as well as their job engagement - our research expands understanding of the individual level antecedents of knowledge work and the importance of personal resources in a challenging form of knowledge work. As such, a better understanding of the role of personal resources for knowledge workers' job engagement might help knowledge workers identify and develop their personal resources, for example, through conscious training (e.g., Wingerden et al., 2015) and education. In particular, the findings indicate that in independent knowledge work an individual must continuously pay attention, maintain, and develop his or her personal resources according to the demands they face (changes in the environment as well as in one's interests). In this way, they may be better able to identify and take advantage of work opportunities more appropriate to their competencies, which is likely to result in increased productivity. As such, the results of the current study contribute to a better understanding of the role of personal resources for independent knowledge work.

This study also makes a contribution to the managerial domain. It does this by providing human resource management professionals with an understanding of the importance of personal resources for knowledge workers' job engagement. An individual's positive self-regard—which reflects high levels of personal resources - is an important part of an organization's humanresource-based competitive strategies (e.g., Lawler, 1992; Pfeffer and Jeffrey, 1998). As the strategic goals of contemporary organizations increasingly concern creating new knowledge and seizing opportunities in the global economy, it is important for strategic human resource management to support employee behaviors that are critical to an organization's strategic goal 
attainment (Schuler and Jackson, 1987). In this way, organizations might enhance their human relations management practices and develop better support mechanisms to enhance the dedication of their university graduated knowledge workers. Moreover, while supporting and developing knowledge workers, human resource professionals should consider the underlying aspects affecting physical, cognitive, and emotional engagement. That is, they should consider personal resources. In an endeavor to foster knowledge workers' personal resources and job engagement, human resource managers may direct specific educational and training activities for knowledge workers. This is particularly important in organizations in which success relies on the critical knowledge of knowledge workers.

\section{Limitations and recommendations for future research}

This study has its limitations, however. One limitation is that the research model is based on only three personal resources: general self-efficacy, organization-based self-esteem, and satisfaction with life. As such, future studies should consider a wider set of personal resources, including hope, optimism, and resilience (Luthans and Youssef, 2004) when investigating the relationship between personal resources and knowledge workers' job engagement.

Another limitation of the present study is that it investigates only the direct effects of general self-efficacy and knowledge workers' job engagement. In previous studies, general self-efficacy has been found to positively affect job engagement. However, in this study, the relationship was found to be negative, although statistically not significant. It is likely that self-efficacy acts as a mediating or moderating mechanism between personal resources and job engagement. Future studies should consider such relations as well. 
To the authors' knowledge, this study was one of the first attempts to validate Rich et al.'s (2010) job engagement scale, as suggested by Jeung (2008), in the knowledge worker context. An interesting avenue for future research would be to compare various job or work engagement scales against the same study sample. This would provide the research community with important information about the suitability of different scales in various work contexts. Finally, while current empirical research on contemporary knowledge work is sparse, the authors suggest that scholars focus their research on the various forms of knowledge work in contemporary work life. 


\section{References}

Abubakar, A. M., Foroutan, T. and Megdadi, K. J. (2019), “An integrative review: Highperformance work systems, psychological capital and future time perspective", International Journal of Organizational Analysis, doi.org/10.1108/IJOA-12-2017-1302.

Airila, A., Hakanen, J. J., Schaufeli, W. B., Luukkonen, R., Punakallio, A. and Lusa, S. (2014), “Are job and personal resources associated with work ability 10 years later? The mediating role of work engagement", Work and Stress, Vol. 28 No. 1, pp. 87-105.

Atkins, M. J. (1999), “Oven-ready and self-basting: taking stock of employability skills”, Teaching in Higher Education, Vol. 4 No. 2, pp. 267-280.

Bailey, T. C., Eng, W., Frisch, M. B. and Snyder, C. R. (2007), "Hope and optimism as related to life satisfaction", The Journal of Positive Psychology, Vol. 2 No. 3, pp. 168-175.

Bakker, A. B. and Demerouti, E. (2008), “Towards a model of work engagement”, Career Development International, Vol. 13 No. 3, pp. 209-223.

Bakker, A. B., Albrecht, S. L. and Leiter, M. P. (2011), “Key questions regarding work engagement”, European journal of Work and Organizational Psychology, Vol. 20 No 1, pp. 428.

Bakker, A. B., Demerouti, E. and Xanthopoulou, D. (2012a), "How do engaged employees stay engaged", Ciencia \& Trabajo, Vol. 14 No. 1, pp. 15-21. 
Bakker, A. B., Schaufeli, W. B., Leiter, M. P. and Taris, T. W. (2008), "Work engagement: An emerging concept in occupational health psychology”, Work and Stress, Vol. 22 No. 3, pp. 187220.

Bakker, A. B., Tims, M. and Derks, D. (2012b), "Proactive personality and job performance: The role of job crafting and work engagement”, Human Relations, Vol. 65 No. 10, pp. 1359-1378.

Bandura, A. (1977), "Self-efficacy: Toward a unifying theory of behavioral change", Psychological Review, Vol. 84 No. 2, pp. 191-215.

Bandura, A. (1993), "Perceived self-efficacy in cognitive development and functioning", Educational Psychologist, Vol. 28 No. 2, pp. 117-148.

Bandura, A. (1997), Self-efficacy: the exercise of control, Freeman, New York, NY.

Barrick, M. R., Mount, M. K. and Li, N. (2013), "The theory of purposeful work behavior: The role of personality, higher-order goals, and job characteristics", Academy of Management Review, Vol. 38 No. 1, pp. 132-153.

Burke, R. J. and Ng, E. (2006), “The changing nature of work and organizations: Implications for human resource management”, Human Resource Management Review, Vol. 16, pp. 86-94.

Chen, G., Gully, S. M. and Eden, D. (2001), "Validation of a new general self-efficacy scale", Organizational Research Methods, Vol. 4 No. 1, pp. 62-83.

Childers, T. L., Carr, C. L., Peck, J. and Carson, S. (2001), "Hedonic and utilitarian motivations for online retail shopping behavior", Journal of Retailing, Vol. 77, pp. 511-535. 
Consiglio, C., Borgogni, L., Di Tecco, C. and Schaufeli, W. B. (2016), "What makes employees engaged with their work? The role of self-efficacy and employee's perceptions of social context over time", Career Development International, Vol. 21 No. 2, pp. 125-143.

Davenport, T. H., Thomas, R. J., Cantrell, S. and De Long, D. W. (2002), “The art of work: Facilitating the effectiveness of high-end knowledge workers", Accenture Institute for Strategic Change.

Diamantopoulos, A. and Siguaw, J. A. (2000), Introducing LISREL, Sage Publications, Thousand Oaks, CA.

Diener, E., Emmons, R. A., Larsen, R. J. and Griffin, S. (1985), “The satisfaction with life scale", Journal of Personality Assessment, Vol. 49 No. 1, pp. 71-75.

Diener, E., Suh, E. M., Lucas, R. E. and Smith, H. L. (1999), “Subjective well-being: Three decades of progress", Psychological Bulletin, Vol. 125 No. 2, pp. 276-302.

Dul, J., Ceylan, C. and Jaspers, F. (2011), 'Knowledge workers' creativity and the role of the physical work environment”, Human Resource Management, Vol. 50 No. 6, pp. 715-734.

Erdogan, B., Bauer, T. N., Truxillo, D. M. and Mansfield, L. R. (2012), "Whistle while you work: A review of the life satisfaction literature," Journal of Management, Vol. 38 No. 4, pp. $1038-1083$

Fisher, R. J. and Price, L. L. (1992), “An investigation into the social context of early adoption behavior", Journal of Marketing Research, Vol. 19 No. 3, pp. 477-486. 
Fornell, C. and Larcker, D. F. (1981), "Evaluating structural equation models with unobservable variables and measurement error", Journal of Marketing Research, Vol. 18 No. 1, pp. 39-50.

Forret, M. L. and Dougherty, T. W. (2001), "Correlates of networking behavior for managerial and professional employees", Group and Organizational Management, Vol. 26 No. 3, pp. 283311.

Gardner, D. G. and Pierce, J. L. (1998), "Self-esteem and self-efficacy within the organizational context", Group and Organization Management, Vol. 23 No. 1, pp. 48-70.

Gilson, L. L., Maynard, M. T., Jones Young, N. C., Vartiainen, M. and Hakonen, M. (2015), "Virtual teams research: 10 years, 10 themes, and 10 opportunities", Journal of Management, Vol. 41 No. 5, pp. 1313-1337.

Grawitch, M. J., Barber, L. K. and Justice, L. (2010), “Rethinking the work-life interface: It's not about balance, it's about resource allocation," Applied Psychology: Health and Well-Being, Vol. 2 No. 2, pp. 127-159.

Greenberg, J., Solomon, S., Pyszczynski, T., Rosenblatt, A., Burling, J., Lyon, D. and Pinel, E. (1992), "Why do people need self-esteem? Converging evidence that self-esteem serves an anxiety-buffering function”, Journal of Personality and Social Psychology, Vol. 63 No. 6, pp. $913-922$.

Hakanen, J. (2009), Työn imun arviointimenetelmä (Utrecht Work Engagement Scale), Työterveyslaitos, Helsinki. 
Hakanen, J. J. and Lindbohm, M. L. (2008), "Work engagement among breast cancer survivors and the referents: The importance of optimism and social resources at work", Journal of Cancer Survivorship, Vol. 2 No. 4, pp. 283-295.

Hakanen, J. J., Rodríquez-Sánchez, A. M. and Perhoniemi, R. (2012), “Too good to be true? Similarities and differences between engagement and workaholism among Finnish judges", Ciencia \& Trabajo, Vol. 14, pp. 72-80.

Hallberg, U. and Schaufeli, W. B. (2006), “Same same but different? Can work engagement be discriminated from job involvement and organizational commitment?", European Psychologist, Vol. 11 No. 2, pp. 119-127.

Hobfoll, S. E. (1989), "Conservation of resources a new attempt at conceptualizing stress", American Psychologist, Vol. 44 No. 3, pp. 513-524.

Hobfoll, S. E. (2011), “Conservation of resource caravans and engaged settings”, Journal of Occupational and Organizational Psychology, Vol. 84 No. 1, pp. 116-122.

Imperatori, B. (2017), Engagement and Disengagement at Work: Drivers and Organizational Practices to Sustain Employee Passion and Performance, Springer International Publishing, New York, NY.

Jeung, C.-W. (2011), “The Concept of Employee Engagement: A Comprehensive Review from a Positive Organizational Behavior Perspective", Performance Improvement Quarterly, Vol. 24 No. 2, pp. 49-69.

Kahn, W. A. (1990), "Psychological conditions of personal engagement and disengagement at work", Academy of Management Journal, Vol. 33 No. 4, pp. 692-724. 
Kelloway, E. K. and Barling, J. (2000), “Knowledge work as organizational behaviour”. International Journal of Management Reviews, Vol. 2 No. 3, pp. 287-304.

Lawler, E. E. (1992), The ultimate advantage: creating the high-involvement organization, Josey-Bass, San Francisco, CA.

Luthans, F. and Youssef, C. M. (2004), "Human, social, and now positive psychological capital management: Investing in people for competitive advantage", Organizational Dynamics, Vol. 33 No. 2, pp. 143-160.

Luthans, F., Avey, J. B., Avolio, B. J. and Peterson, S. J. (2010), “The development and resulting performance impact of positive psychological capital”, Human Resource Development Quarterly, Vol. 21 No. 1, pp. 41-67.

Luthans, F., Avolio, B. J., Avey, J. B. and Norman, S. M. (2007), "Positive psychological capital: Measurement and relationship with performance and satisfaction", Personnel Psychology, Vol. 60 No. 3, pp. 541-572.

Maslach, C., Schaufeli, W. B. and Leiter, M. P. (2001), “Job burnout”, Annual Review of Psychology, Vol. 52, pp. 397-422.

Mauno, S., Kinnunen, U. and Ruokolainen, M. (2007), “Job demands and resources as antecedents of work engagement: A longitudinal study"; Vocational Behavior, Vol. 70, pp. 149171. 
O’Neill, T. A., Hambley, L. A. and Chatellier, G. S. (2014), “Cyberslacking, engagement, and personality in distributed work environments", Computers in Human Behavior, Vol. 40, pp. 152160.

Pfeffer, J. and Jeffrey, P. (1998), The human equation: Building profits by putting people first, Harvard Business Press.

Pierce, J. L. and Gardner, D. G. (2004), "Self-esteem within the work and organizational context: A review of the organization-based self-esteem literature", Journal of Management, Vol. 30 No. 5, pp. 591-622.

Pierce, J. L., Gardner, D. G., Cummings, L. L. and Dunham, R. B. (1989), “Organization-based self-esteem: Construct definition, measurement, and validation", Academy of Management Journal, Vol. 32 No. 3, pp. 622-648.

Rich, B. L., Lepine, J. A. and Crawford, E. R. (2010), "Job engagement: Antecedents and effects on job performance", Academy of Management Journal, Vol. 53 No. 3, pp. 617-635.

Rüdiger, K., and McVerry, A. (2007), Exploiting Europe's knowledge potential: 'Good work' or 'could do better'. Knowledge work and knowledge workers in Europe, A report prepared for the Knowledge Economy Programme, London, The Work Foundation.

Saks, A. M. (2006), “Antecedents and consequences of employee engagement”, Journal of Managerial Psychology, Vol. 21 No. 7, pp. 600-619.

Saks, A. M. and Gruman, J. A. (2014), "What do we really know about employee engagement?", Human Resource Development Quarterly, Vol. 25 No. 2, pp. 155-182. 
Salanova, M., Bakker, A. B. and Llorens, S. (2006), "Flow at work: Evidence for an upward spiral of personal and organizational resources", Journal of Happiness Studies, Vol. 7 No. 1, pp. $1-22$.

\begin{abstract}
Salanova, M., Llorens, S., Cifre, E., Martínez, I. M. and Schaufeli, W. B. (2003), "Perceived collective efficacy, subjective well-being and task performance among electronic work groups an experimental study", Small Group Research, Vol. 34 No 1, pp. 43-73.
\end{abstract}

Salanova, M., Peiró, J. M. and Schaufeli, W. B. (2002), "Self-efficacy specificity and burnout among information technology workers: An extension of the job demand-control model”, European Journal of Work and Organizational Psychology, Vol. 11 No. 1, pp. 1-25.

Scarbrough, H. (1999), "Knowledge as work: Conflicts in the management of knowledge workers", Technology Analysis \& Strategic Management, Vol. 11 No 1, pp. 5-16.

Schaufeli, W. (2013), “What is engagement?”, in Truss, C., Alfes, K., Delbridge, R., Shantz, A. and Soane, E. (Eds.), Employee Engagement in Theory and Practice, Routledge, London, pp. 137.

Schaufeli, W. and Bakker, A. B. (2010). "Defining and measuring work engagement: Bringing clarity to the concept" in Bakker, A. B. and Leiter, M. P. (Eds.), Work Engagement. A Handbook of Essential Theory and Research, Psychology Press, New York, NY. pp. 10-24.

Schaufeli, W. and Salanova, M. (2007), "Work engagement an emerging psychological concept and its implications for organizations", in Gilliland, S. W., Steiner, D. D. and Skarlicki, D. P. (Eds.), Managing Social and Ethical Issues in Organizations, Information Age Publishing, Greenwich, Connecticut, pp. 135-177. 
Schaufeli, W. B., Salanova, M., González-Roma, V. and Bakker, A. B. (2002), “The measurement of engagement and burnout: A two sample confirmatory factor analytical approach”, Journal of Happiness Studies, Vol. 3, pp. 71-92.

Schaufeli, W. B., Taris, T. W. and van Rhenen, W. (2008), "Workaholism, burnout, and work engagement: Three of a kind or three different kinds of employee well-being?", Applied Psychology: An International Review, Vol. 57 No. 2, pp. 173-203.

Scholz, U., Doña, B. G., Sud, S. and Schwarzer, R. (2002)”, Is general self-efficacy a universal construct? Psychometric findings from 25 countries", European Journal of Psychological Assessment, Vol. 18 No. 3, pp. 242-251.

Schuler, R. S. and Jackson, S. E. (1987), "Linking competitive strategies with human resource management practices", The Academy of Management Executive (1987-1989), pp. 207-219.

Seligman, E. P. and Csikszentmihalyi, M. (2000), "Positive Psychology - An Introduction”, American Psychologist, Vol. 55 No. 1, pp. 5-14.

Sherer, M., Maddux, J. E., Mercandante, B., Prentice-Dunn, S., Jacobs, B. and Rogers, R. W. (1982), “The Self-efficacy scale: Construction and validation”, Psychological Reports, Vol. 51, pp. 663-671.

Shin, D. C. and Johnson, D. M. (1978), “Avowed happiness as an overall assessment of the quality of life", Social Indicators Research, Vol. 5 No. 1-4, pp. 475-492.

Shuck, B. (2011), "Four emerging perspectives of employee engagement: An integrative literature review", Human Resource Development Review, Vol. 10 No. 3, pp. 304-328. 
Sonnentag, S. (2003), "Recovery, work engagement, and proactive behavior: A new look at the interface between nonwork and work", Journal of Applied Psychology, Vol. 88 No. 3, pp. 518528.

Sullivan, S. E., Forret, M. L., Mainiero, L. A. and Terjesen, S. (2007), "What motivates entrepreneurs? An exploratory study of the kaleidoscope career model and entrepreneurship", Journal of Applied Management and Entrepreneurship, Vol. 12 No. 4, pp. 4-19.

Sweetman, D. and Luthans, F. (2010). “The power of positive psychology: Psychological capital and work engagement” in Bakker, A. B. and Leiter, M. P. (Eds.), Work Engagement. A Handbook of Essential Theory and Research, Psychology Press, New York, NY. pp. 54-68.

Thompson, J. A. (2005), "Proactive personality and job performance: A social capital perspective", Journal of Applied Psychology, Vol. 90 No. 5, pp. 1011-1017.

Turner, T. and Pennington, W. W. (2015), “Organizational networks and the process of corporate entrepreneurship: How the motivation, opportunity, and ability to act affect firm knowledge, learning, and innovation”, Small Business Economics, Vol. 45, pp. 447-463.

Van Wingerden, J., Derks, D. and Bakker, A. B. (2015), “The impact of personal resources and job crafting interventions on work engagement and performance", Human Resource Management, Vol. 56 No. 1, pp. 51-67.

Von Nordenflycht, A. (2010), "What is a professional service-firm? Toward a theory and taxonomy of knowledge-intensive firms", Academy of Management Review, Vol. 35 No. 1, pp. $155-174$. 
Xanthopoulou, D., Bakker, A. B., Demerouti, E. and Schaufeli, W. B. (2009), "Reciprocal relationships between job resources, personal resources, and work engagement", Journal of Vocational Behavior, Vol. 74 No. 3, pp. 235-244.

Yalabik, Z. Y., van Rossenberg, Y., Kinnie, N. and Swart, J. (2015), “Engaged and committed? The relationship between work engagement and commitment in professional service firms", The International Journal of Human Resource Management, Vol. 26 No. 12, pp. 1602-1621. 


\section{Table 1}

The Composition of Schaufeli's (2002) Framework for Work-related Engagement

\section{Theories and models in Schaufeli's Key elements for engagement \\ framework}

The needs-satisfying approach (Kahn,

- Three psychological conditions exist:

1990).

meaningfulness, safety, and availability.

- If psychological conditions are satisfied, engagement

is likely to occur.

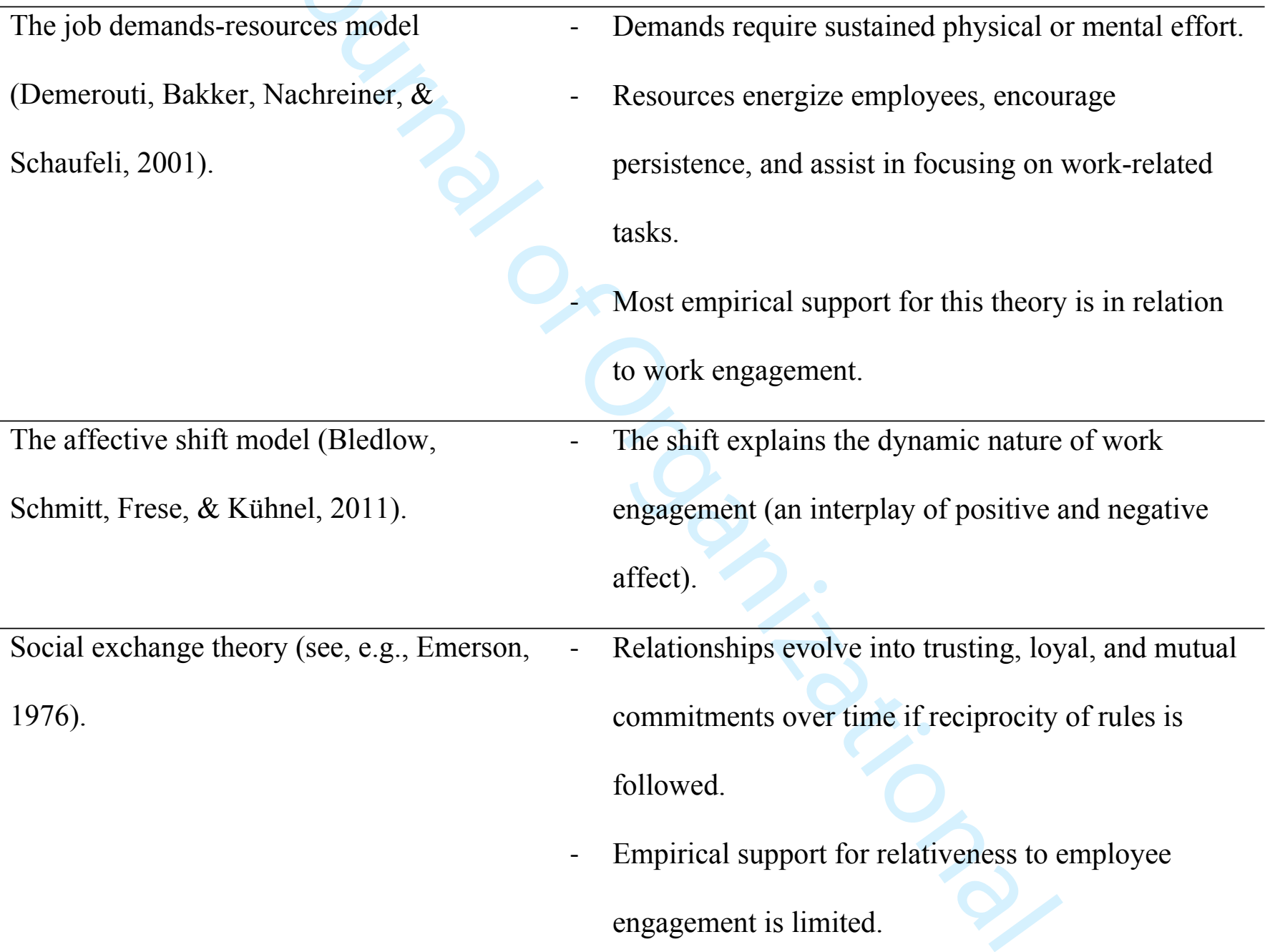


Table 2

Measurement Model for Independent Variables

\section{Constructs and their items}

Self-efficacy
Std. loading CR AVE

0.9040 .701

When facing difficult tasks, I am certain that I will accomplish them. 0.858

I believe I can succeed at almost any endeavor I set my mind to. $\quad 0.813$

I can accomplish most tasks very well.

Even when things are tough, I can perform quite well.

0.852

Organization-based self-esteem

$0.940 \quad 0.724$

I am taken seriously.

0.898

I am trusted.

0.840

I can make a difference.

0.917

I count around here.

0.901

I am cooperative.

0.794

\section{Satisfaction with life}

0.9150 .782

In most ways my life is close to my ideal.

The conditions of my life are excellent.

I am satisfied with my life.

0.897

Goodness of fit: $\chi^{2}(\mathrm{df})=79.8(51) \mathrm{RMSEA}=.079 \mathrm{NFI}=.954 \mathrm{NNFI}=.980$ 


\section{Table 3}

Measurement Model for Job Engagement Dimensions

Std.

\section{Constructs and their items}

Physical engagement

I exert my full effort to my job.

I devote a lot of energy to my job.

I try my hardest to perform well on my job.

I exert a lot of energy on my job.

\section{Emotional engagement}

I am enthusiastic in my job.

I feel energetic at my job.

I am interested in my job.

I feel positive about my job.

I am excited about my job. loading CR AVE

$0.90 \quad 0.69$

0.81

0.88

0.83

0.80
0.92

0.89

0.90

0.90

0.89

\section{Cognitive engagement}

$0.93 \quad 0.77$

While working, I pay a lot of attention to my job.

0.86

While working, I am absorbed by my job.

0.84

While working, I concentrate on my job.

0.89

While working, I devote a lot of attention to my job.

0.92 
Table 4

Results of Structural Model Explaining Dimensions of Job Engagement

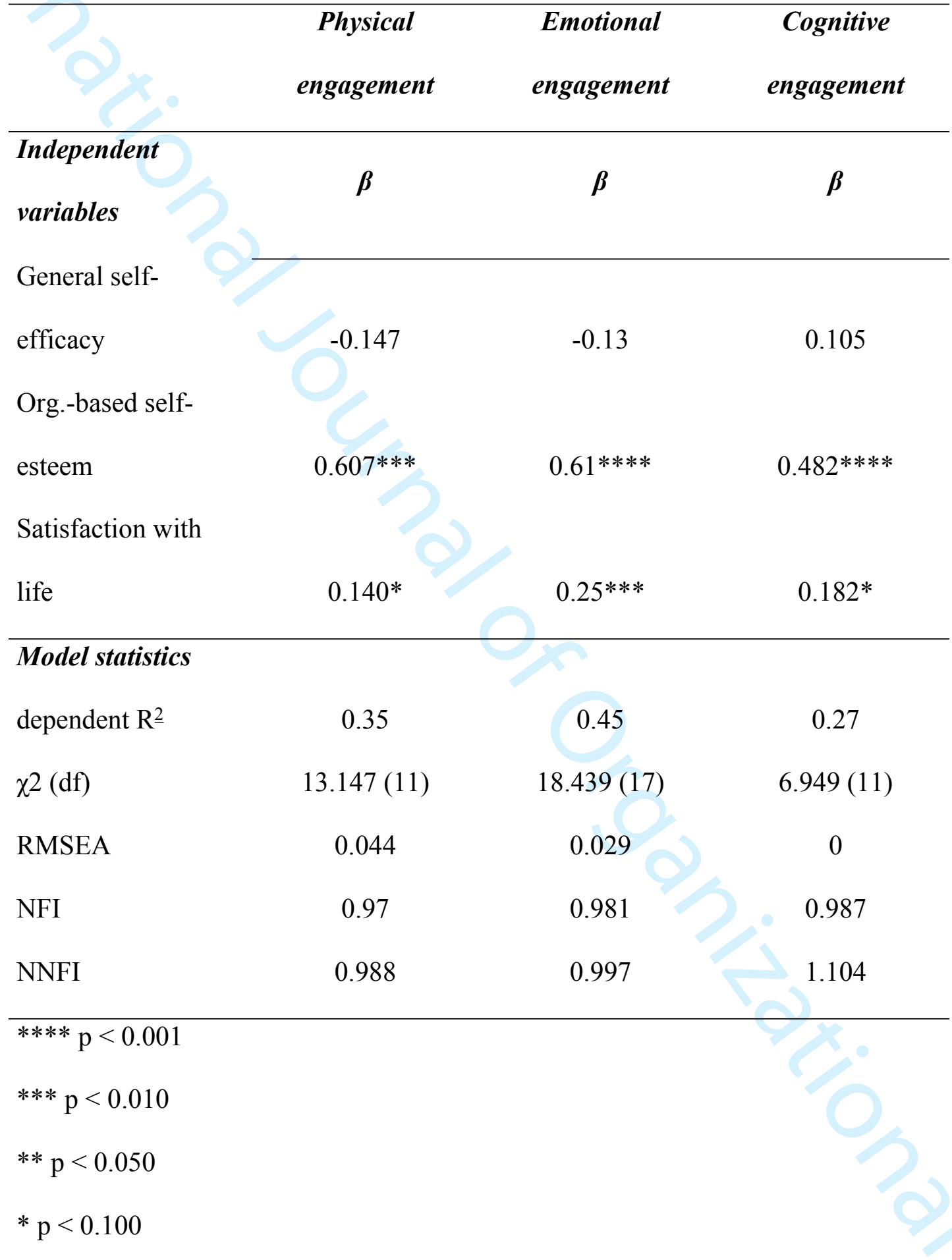




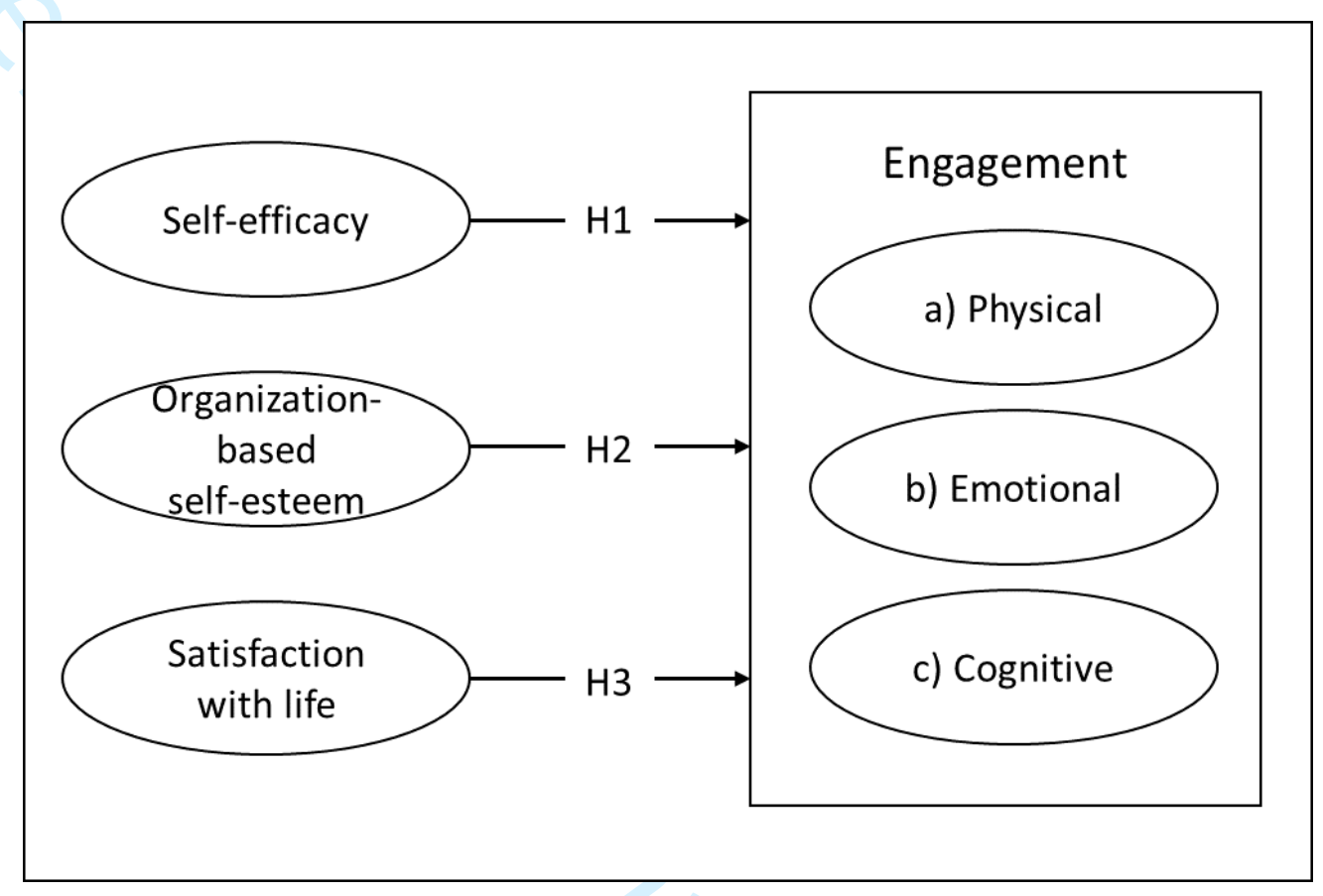

Figure 1. The Research Model 